\title{
BIOCATALYTIC REDUCTION OF KETONES IN A SECONDARY SCHOOL LABORATORY
}

\author{
BIOKATALITYCZNA REDUKCJA KETONÓW \\ W LABORATORIUM SZKOLY ŚREDNIEJ
}

\begin{abstract}
Biocatalysis is one of the most important industrial methods which has been increasingly attracting attention of scientists as a new and environmentally acceptable method. It is used in the preparation of chiral alcohols - important building blocks for the synthesis of fine chemicals, pharmaceuticals, agrochemicals and analogues of natural substances. In biocatalysis the use of traditional chiral agents based on heavy metals has been replaced by the use of enzymes. In many cases, the number of reaction steps has been limited, the selectivity of the desired products has been increased while the negative impact on the environment has been reduced. The principles of biocatalysis have been applied by us to design a simple chemical experiment for the students of higher secondary education. The modified assignment of a lab task consisted of bioreduction of 4-nitroacetophenone using the enzymes present in plant tissues of carrot, parsley and white radish. Within our pedagogical research, the adequacy of the chemical experiment for secondary school students was examined and the extent of understanding of the green chemistry experiment was analysed by the method of a semi-structured interview.
\end{abstract}

Keywords: biocatalysis, green chemistry, enzymes, school experiment, semi-structured interview

\section{Introduction}

Green chemistry is an area of chemistry that involves the application of chemical processes in such a way that the safety of chemical syntheses is increased, the use and production of hazardous substances is reduced in order to eliminate the negative impact on the environment and humans [1]. It is an innovative philosophy in industrial production, but also in chemical education, which includes all aspects of safety and sustainability that are designed to prevent further environmental pollution $[2,3]$.

Biocatalysis is an ideal tool of green chemistry, which uses enzymes as biocatalysts to synthesise a wide range of chemical products. However, it must be emphasised that the use of enzymes is no novelty. In ancient times, ancient Sumers and Babylonians used biochemical enzyme processes based on the activity of wild microorganisms that were applied for hundreds of years in the production of bread, wine, vinegar, beer, dough rising,

\footnotetext{
1 Department of Didactics in Science, Psychology and Pedagogy, Faculty of Natural Sciences, Comenius University in Bratislava, Mlynská dolina, 84215 Bratislava, Slovak Republic, phone +421 260296311 , email: dominika.lacuskova@gmail.com

* Corresponding author: atothova@fns.uniba.sk
} 
cabbage fermentation, production of cheese and other dairy products [4, 5]. Enzymes as such were described much later and caught attention of many researchers and scientific teams.

Enzymes are biocompatible and biodegradable. The reactions catalysed by enzymes are carried out in an aqueous medium, at neutral $\mathrm{pH}$, at room temperature, under normal pressure and have a high catalytic activity. One of the greatest advantages of the use of biocatalysts in enzymatic transformations is high natural selectivity (chemoselectivity, regioselectivity, stereoselectivity), which helps reduce the number of reaction steps compared to reactions catalysed by classical chemical catalysts [6].

Biocatalytic reduction of prochiral ketones is among significant industrial methods used in the preparation of non-racemic chiral alcohols. Optically pure chiral alcohols form important intermediates for the synthesis of fine chemicals, pharmaceuticals, agrochemicals, and analogues of natural substances. There are numerous industrial methods known to prepare these chiral alcohols, including a reduction with expensive chiral reagents based on heavy metals. Several scientific teams are currently seeking inspiration in natural reactions in order to replace chemical processes by biological methods, thereby eliminating negative environmental impacts and reducing overall production costs.

Enzymes produced by plant cells are capable of catalysing the reduction of prochiral ketones with high enantioselectivity. These reactions may be catalysed by isolated enzymes or whole cells. Dehydrogenases play the most important role in bioreduction syntheses [7]. This subclass of enzymes is used in reductions of the carbonyl groups of aldehydes and ketones into corresponding alcohols. Their significance lies in the obtaining a chiral product from the prochiral substrate (Fig. 1).

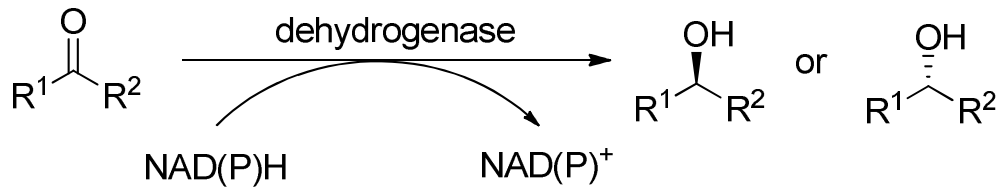

Fig. 1. Use of dehydrogenases in various types of bioreduction reactions with cofactor regeneration

For this reason, dehydrogenases have been successfully applied as reducing agents in the production of chiral hydroxy acids, amino acids, $\alpha$ - and $\beta$-hydroxy esters and in particular chiral alcohols, which form key building blocks of specialty chemicals, agrochemicals and pharmaceuticals [8-10].

The biocatalytic activity of dehydrogenases is dependent on the presence of a low molecular weight non-protein component - a cofactor. The cofactor acts as a reagent and is consumed in stoichiometric proportions to the substrate. The most common cofactors used in the reduction reactions are nicotinamide adenine dinucleotide [NAD $(H)]$ and its phosphate $[\mathrm{NADP}(\mathrm{H})]$, which usually enter chemical reactions in low concentrations. If the reaction is to be carried out continuously, it is necessary to work with a system that allows its regeneration (Fig. 2). 


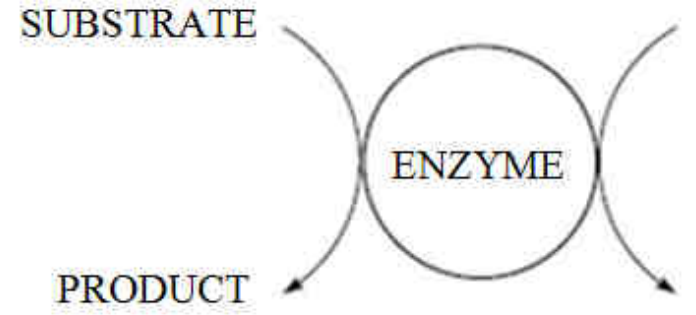

Fig. 2. General scheme of cofactor regeneration

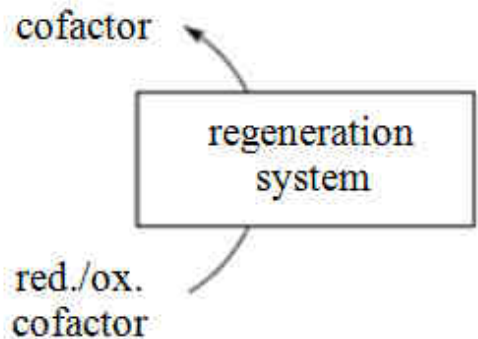

There are several well-known chemical strategies used for cofactor recycling. In recent years, attention has been increasingly drawn to the application of whole cells of microorganisms or plant tissues. They contain the necessary enzymes and cofactors regenerated in the process of metabolism of the cell itself. In this way it is possible to replace the use of isolated dehydrogenases in bioreduction syntheses, thus eliminating the problem of expensive cofactor recycling [11, 12].

There are several reaction systems found in the literature describing the synthesis of chiral secondary alcohols using different parts of plant tissues [13, 14]. Since 2000, the plant tissues of carrots have been repeatedly used as biocatalysts for stereoselective ketone reduction. Acetophenone and its derivatives are probably among the most studied substrates for enatioselective bioreduction into corresponding alcohols.

Topicality, interdisciplinary character and in particular, connection with ordinary life, make green chemistry an ideal theme that should find its place in the science lessons. Certain teaching methods, e.g. group or cooperative teaching, create room for discussion, problem solving, presenting student's opinions and beliefs. These approaches support the linkage of chemistry with everyday life, increase the motivation of students and shape their attitude to the responsibility for their own actions, which can have an impact on the environment as well as future generations.

In a school lab, especially in organic chemistry experiments, we often encounter some limitations due to the lack of time, laboratory aids and chemicals. As a result, students are not allowed to work independently in terms of safety and currently valid legislation. For these reasons, an attempt to eliminate the use of fume hoods, toxic solvents and reactants is the main motivation in doing experiments using the principles of green chemistry.

\section{Methodology}

The aim of our research was to design a simple and safe school experiment for the students of higher secondary education based on the research conducted in scientific laboratories. We tested multiple substrates and various kinds of plant tissues in a school lab. Based on the results obtained, we created a chemical experiment assignment that met our predefined requirements. The requirements concerned a safety and time aspect and also the availability of the used chemicals. We adjusted the experiment procedure to such an extent that its realisation is feasible in secondary school conditions. Moreover, the students were also provided a set of preliminary tasks not to test their knowledge, but to recall and revise the curriculum on carbonyl compounds and basic laboratory methods they were expected to encounter during the experiment. 


\section{Optimization}

As mentioned above, our research was based on the experiments conducted in scientific laboratories. Firstly, we used acetophenone $(0.2 \mathrm{~g})$ as a substrate for biotransformation in a reaction with plant cells $(80 \mathrm{~g})$ of potato, sweet potato, carrot, parsley, cucumber, apple, and white radish. The tissues were grated into larger pieces and incubated for seven days at room temperature. After the reaction was complete, the plant tissue was filtered off and the filtrate was extracted with ethyl acetate.

When checking the product purity by Thin Layer Chromatography (TLC), we found out that complete conversion of the ketone to alcohol did not take place. Moreover, there was no reduced product observed for plant tissues of potato, sweet potato, apple and cucumber. In the next optimization we only used carrot, parsley and white radish tissues. The amount of plant tissue was doubled and mixed. After a week of incubation we found out that the conversion was incomplete and the starting material was also present in the product.

Subsequently, a more reactive 4-nitroacetophenone was chosen as the substrate. It $(0.2 \mathrm{~g})$ was dissolved in ethanol $\left(2 \mathrm{~cm}^{3}\right)$ and added to a suspension of freshly mixed carrot/parsley/white radish plant tissue $(160 \mathrm{~g})$. The reaction mixture was stirred with a magnetic stirrer at room temperature for seven days. When checking the product purity by TLC method, it was evident that the conversion was complete and the starting material was not present in the obtained product (Fig. 3).

The obtained product 1-(4-nitrophenyl)ethanol was subjected to ${ }^{1} \mathrm{H}$ NMR spectroscopy $\left[\mathrm{C}_{8} \mathrm{H}_{9} \mathrm{O}_{3} \mathrm{~N}, \mathrm{Mr}=168 ;{ }^{1} \mathrm{H} \mathrm{NMR}\left(\mathrm{CDCl}_{3}, 600 \mathrm{MHz}\right): 8.20\left(\mathrm{~d}, J=9.0 \mathrm{~Hz}, 2 \mathrm{H}_{\mathrm{ar}}\right) ; 7.55\right.$ $\left.\left(\mathrm{d}, J=9.0 \mathrm{~Hz}, 2 \mathrm{H}_{\mathrm{ar}}\right) ; 5.03(\mathrm{q}, J=6.0 \mathrm{~Hz}, 1 \mathrm{H}) ; 1.53(\mathrm{~d}, J=6.0 \mathrm{~Hz}, 3 \mathrm{H})\right]$ and the optical rotation $\left[[\alpha]_{\mathrm{D}}^{20}=-4.75\left(\mathrm{c}=1, \mathrm{CHCl}_{3}\right)\right]$ was also measured. The measured values were consistent with the values reported in the literature [15].

Based on the results obtained by optimization, we designed the experiment assignment and modified the procedure to such an extent that it is feasible in secondary school conditions.

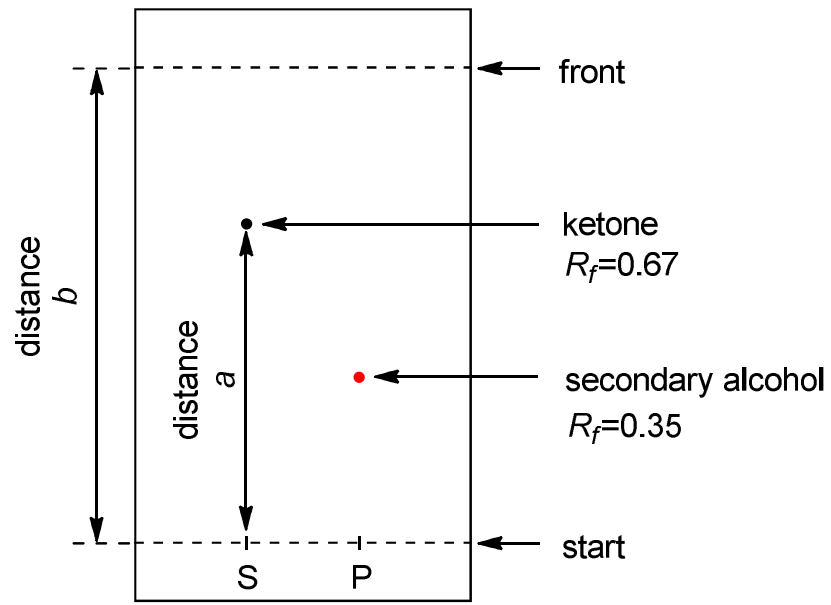

S-standard; P-product; $R_{f}$-retardation factor

Fig. 3. TLC plate 


\section{Research}

The pedagogical research was held in February and March 2017 with a target group of 8 students $-3^{\text {rd }}$ graders from a Bratislava secondary school. During the research, we used a method of structured observation to monitor the extent of students' abilities to work independently on the assigned tasks. We wanted to find out whether this experiment was designed sufficiently to be understood by secondary school students and whether its realisation, in terms of time, is feasible in a chemistry lesson. We measured the time spent by the students in each step of the procedure and noted down any problems that arose during the experiment. This helped us modify the procedure to make it as simple as possible. During the first lab practical the students set a reaction system following the procedure instructions and let it stir using a magnetic stirrer for seven days. After a week, they returned to the school lab and proceeded according to the instructions and evaluated the results of the chemical experiment.

In the last part of pedagogical research, we tried to find out the extent of understanding the experiment principle in the form of a semi-structured interview. Students' interviews were conducted individually in the school lab environment for about 20 minutes and were recorded. Afterwards, verbatim transcripts from the recordings were made and their content was qualitatively evaluated. During the interviews, we tried to create a pleasant atmosphere to make the students answer the questions in a way they really perceive and understand the individual phenomena. We also took a great care to prevent the students from influencing each other and thus not distorting the research results.

\section{Results}

The experiment assignment included six preliminary tasks with a free answer. The summary of students' answers is presented in Table 1. The set of tasks served as a pre-preparation for the lab practical. The tasks were designed to revise the curriculum on carbonyl compounds and the basic laboratory methods they were expected to encounter during the experiment.

Table 1

Evaluation of students' answers to preliminary tasks

\begin{tabular}{|c|c|c|c|c|c|c|c|c|}
\hline \multirow{3}{*}{ Task } & \multicolumn{9}{|c|}{ Evaluation of students' answers } \\
\cline { 2 - 9 } & \multicolumn{2}{|c|}{ Correct } & \multicolumn{2}{c|}{ Partially correct } & \multicolumn{2}{c|}{ Incorrect } & \multicolumn{2}{c|}{ No answer } \\
\cline { 2 - 9 } & $\begin{array}{c}\text { Number } \\
\text { of students }\end{array}$ & $\begin{array}{c}{[\%]} \\
\text { evaluation }\end{array}$ & $\begin{array}{c}\text { Number } \\
\text { of students }\end{array}$ & $\begin{array}{c}{[\%]} \\
\text { evaluation }\end{array}$ & $\begin{array}{c}\text { Number } \\
\text { of students }\end{array}$ & $\begin{array}{c}{[\%]} \\
\text { evaluation }\end{array}$ & $\begin{array}{c}\text { Number } \\
\text { of students }\end{array}$ & $\begin{array}{c}{[\%]} \\
\text { evaluation }\end{array}$ \\
\hline 1 & 1 & 12.5 & 7 & 87.5 & 0 & 0.0 & 0 & 0.0 \\
\hline 2 & 3 & 37.5 & 0 & 0.0 & 4 & 50.0 & 1 & 12.5 \\
\hline 3 & 8 & 100.0 & 0 & 0.0 & 0 & 0.0 & 0 & 0.0 \\
\hline 4 & 7 & 87.5 & 0 & 0.0 & 1 & 12.5 & 0 & 0.0 \\
\hline 5 & 0 & 0.0 & 2 & 25.0 & 0 & 0.0 & 6 & 75.0 \\
\hline 6 & 8 & 100.0 & 0 & 0.0 & 0 & 0.0 & 0 & 0.0 \\
\hline
\end{tabular}

In Task 1, the students were asked to write rational formulae of five arbitrary aliphatic carbonyl compounds and name them. Only one student answered this task correctly, while the other seven students gave partially correct answers. The latter ones included also cyclic chains of carbonyl compounds, named those compounds incorrectly or gave no chemical name (Fig. 4). 


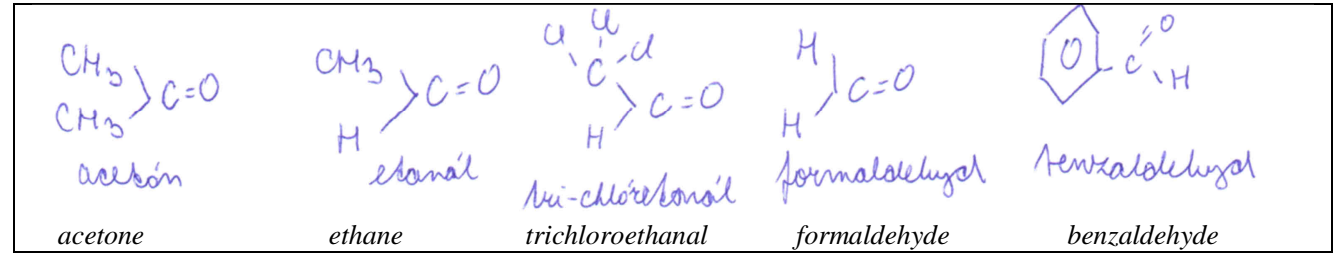

Fig. 4. Example of answer to Task 1

Task 2 was answered correctly by three pupils, while incorrect reactivity order of the given carbonyl compounds was determined by four students. They either considered ketones more reactive than aldehydes or arranged the hydrocarbons downwards according to the length of the hydrocarbon chain regardless of the functional group. One student did not answer the task at all.

In Task 3, the students were asked to determine partial charges on carbon and oxygen atoms of the carbonyl group. All the students answered this task correctly. Moreover, the two of them even gave an explanation of why the oxygen has a negative and the carbon has a positive charge (Fig. 5).

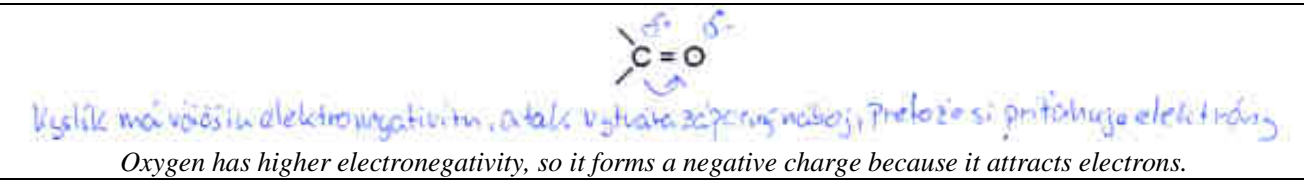

Fig. 5. Example of answer to Task 3

Task 4 was responded correctly by seven students. One student mistakenly introduced a nucleophilic substitution as a characteristic reaction of carbonyl compounds.

Task 5 was not answered by six pupils. Two students partially indicated a mechanism of the reaction of 4-nitroacetophenone with a nucleophilic particle. Since these mechanisms were not complete, they both incorrectly wrote down the formula of the starting substance and did not state that the secondary alcohol was a product, we considered their answers as partially correct (Fig. 6).

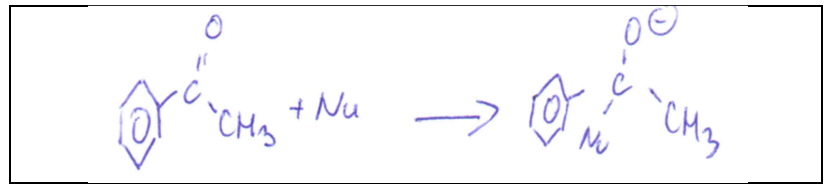

Fig. 6. Example of answer to Task 5

In Task 6, the students were asked to draw a filtration apparatus and briefly describe this laboratory method. All the students gave correct answers.

After the experiment, we were interested in students' feedback regarding the experiment realisation. As a research tool we used an interview. The interview with the students allowed us to explore their understanding of enzymes and their catalytic function more deeply and thoroughly. It is important to note that the interview was not pre- 
structured. The set of questions prepared was only an orientation line. Each interview was held individually and developed based on the student's answers. Our observation was that some students were responsible in answering questions and expressed their ideas in a clear and concise way. The others answered in a chaotic way, they did not think too much about the question asked, and thus we had to ask them more and give them additional questions.

According to the answers collected, none of the students had encountered the term of biocatalyst before our research. However, based on the students' answers, we can conclude that the students associate this term with catalysis and accelerating the course of chemical reactions. The answers also included the characteristic of biocatalysis as a process that accelerates reactions in living organisms by means of catalysts. The vast majority of students briefly replied that enzymes in plant cells and bodies of all organisms or proteins are among these substances. According to one student, oxygen is a substance without which many reactions would not occur in nature.

Asked how the catalyst affects the chemical reaction, the students answered very briefly and correctly that the presence of the catalyst would accelerate, regulate or reduce the value of the activation energy. They were also right when stating that the catalyst does not affect the balance of the chemical reaction. Only one student was wrong when assuming that if the catalyst is a substance that is added to the reaction system, so it logically must also affect the balance.

The students were also asked about the difference in the principle of a chemical reaction regulated by a biocatalyst and an artificially produced catalyst. All students agreed that the nature of the reaction is, in principle, the same regardless of the origin of the catalyst. In their answers, most of the respondents said that all catalysts affect the rate of chemical reaction and remain unchanged after it finishes. Among the most frequently stated benefits of biocatalysts the students included that they are ecological, environmentally friendly and can be obtained from natural sources. There was also one interesting answer of a student who, unlike his classmates, compared the pros and cons of both catalysts and summarised his thoughts as follows: The advantage of biocatalysts is environmental friendliness and the disadvantage is volatility of living material. The advantage of traditional chemical catalysts is that the tested reaction always runs the same way, and the disadvantage is that it is harmful to the environment.

The question regarding the mechanism of the enzyme-catalysed reaction was not clear to every student. One student was not able to answer the question and two other students did not understand the question. The responses of other students weren't significantly different, they characterised the course of the enzyme reaction in a very simple way as a phenomenon when enzyme with the substrate form a complex, which turns into a product.

Enzymes are highly specific organic macromolecules, so we asked students whether they can catalyse any type of a chemical reaction. The students were either convinced that they can or were clearly against. The students, who thought one enzyme was capable of regulating any reaction, could not explain their statement. Those, who thought the opposite, were right and were also able to defend their opinion. As a demonstration, one of the students responded: Enzymes are specific substances of a protein nature that catalyse the conversion of a particular substrate to a particular product. Thus, one enzyme can catalyse only the given reaction and no other.

A series of other questions were directly related to the chemical experiment that the students performed independently in the school lab. We started asking the students to explain the chemical nature of the experiment. Their answers were rather concise and 
simple, as follows: using carrots, we reduced the ketone to alcohol or we put the ketone with the carrot into a flask and after a week of mixing we evaluated whether the reaction was carried out. Several students formulated their answers in a clearer way when saying that the enzymes in plant tissue play a role of a catalyst that initiates the chemical transformation of ketone into alcohol.

When questioned whether the reaction could have occurred without the presence of plant tissue, the students clearly answered that it could not. When asked why it is important to stir the reaction mixture for a period of seven days, two pupils responded: to prevent deposits, lumps and precipitates and to mix everything together nicely. Such formulations cannot be considered correct or relevant in our case. The rest of the students were thinking about the question more carefully and their reasons were as follows to make the ketone react with the greatest possible amount of the tissue. These students responded correctly because they realised that the plant tissue cut into small pieces did not contain a large amount of the enzyme. For this reason, it is important to ensure a contact of the ketone with as many small chopped pieces of the tissue as possible and to ensure that the reaction takes place for a sufficiently long time until the substrate is completely consumed. Based on the interviews we can also assume that the pupils found it difficult to correctly determine the chemical name of the product according to the valid rules of chemical nomenclature. Students' answers included names such as 4-nitrophenyl ethanol, 4-nitrobenzene ethanol, nitro phenyl ethanol.

There is the evidence that the rate of an enzyme-catalyzed reaction can be affected by various factors. Therefore, we asked the students how the course of our experiment could have been accelerated. The most commonly cited factor was temperature. We were also interested in how the students perceived the impact of temperature on the rate of enzyme reaction. Most students were familiar with the fact that raising the temperature increases the rate of a chemical reaction. However, there is a difference in case of reactions catalysed by enzymes.

Enzymes are protein substances that are damaged above $37^{\circ} \mathrm{C}$ and lose their catalytic function. Most students realised that during the interview stating that the plant tissue is due to high temperature cooked and enzymes lose their activity, others used the term denaturation. Apart from the impact of temperature on the rate of chemical reaction, the following factors, such as $\mathrm{pH}$ of the environment, plant size, concentration were also found among students' answers.

The last question was related to laboratory methods. Students were asked to characterise individual methods used in the laboratory practical. In case of extraction, they said most frequently that it is a method using a separating funnel, in which two immiscible layers are formed. Most pupils also knew how to correctly interpret its chemical essence: it is a separation method in which it is possible to get one component from a liquid mixture by adding an extracting agent. Another one simply stated that we leached our product from water in an organic solvent.

We used TLC method to prove the presence of the reduced alcohol. Most students only recalled little balls in different distance from the start that were observed under UV light. The two students were able to characterise chromatography as a method in which a mixture of substances is separated due to different polarity. A plate represents a stationary phase which allows a gradual travelling of the mobile phase. 


\section{Discussion}

Based on the observation results, we can conclude that the students are able to work independently according to a prepared chemical experiment assignment, to do the chemical experiment and complete it within the given time limit. Students did not have any questions concerning the misunderstanding of the experiment procedure in the course of the lab practical - they followed our instructions when working with chemicals and laboratory instruments.

According to the interview analysis, the understanding of the essence of the chemical experiment was, with respect to the school education programme, of a very high level in secondary school $3^{\text {rd }}$ graders. In general, most pupils correctly characterised the term biocatalysis, understood the function of enzymes as catalysts of chemical reactions and explained the principle of biocatalysed reduction of ketones to the respective secondary alcohols. In the overall assessment, we took into account that each student perceives the observed phenomena differently and that prior detailed theoretical knowledge of the given topic is inevitable for correct interpretation of the essence of the observed phenomena. Thus, we assume that the tested experiment is suitable for a category of students who had already had a common chemistry lesson on enzymes. In addition, the experiment can also be performed in a chemistry club or may be an appropriate part of preparation courses for graduates planning to continue their chemistry studies at universities.

If the experiment was to be carried out again in the future, we would recommend the teachers to divide the students into more groups and include also plant tissues that are not able to convert ketone to alcohol (e.g. apple or potato). We are proposing this modification because some students were wrong when asked about whether enzymes can catalyse any type of a chemical reaction. We can assume that each plant tissue contains a different kind of enzyme, and not every enzyme is capable of controlling and regulating the given reduction of ketone to alcohol. The involvement of these tissues in the experiment procedure could support the demonstration of the specific effects of enzymes.

\section{Conclusion}

When preparing the chemical experiment, we were inspired by the available literature describing the preparation of chiral alcohols from prochiral ketones catalysed by cells of various plant tissues. When selecting a suitable substrate and other chemicals, we carefully focused on the choice of appropriate ketones and organic solvents, which are financially available and, in terms of safety, suitable for students working in common lab conditions. Finally, we selected 4-nitroacetophenone as a substrate, which was reduced to the respective chiral 1-(4-nitrophenyl)ethanol with the enzymatic system of plant cells of carrot, parsley and white radish.

We adjusted the experiment procedure to such an extent that it is feasible in secondary school lab conditions. From the experiment procedure for students we omitted a step of product purification and a quantitative analysis in the form of measuring ${ }^{1} \mathrm{H}$ NMR spectra and optical rotation of the product. The results of these measurements had originally served to verify and specify the structure of the reduced product. However, it had been verified by us that stains on the TLC plate are sufficiently visible under UV light, even if we apply the organic phase, obtained immediately after extraction, to the plate in multiple layers. With regard to a number of chemistry lessons at secondary schools, the mixing time of the reaction mixture was set at seven days. 
Preparation of the reaction mixture by the students in a chemistry lesson one week and the subsequent evaluation of the experiment results the next week seemed to us as the most practical solution of how to achieve the best realisation of the student experiment.

The designed experiment was verified in school conditions during our research involving 3rd grade secondary school students in February and March 2017. By using an appropriate means of pedagogical research - a semi-structured interview, we tried to evaluate the degree of understanding of the experiment as well as the ability of students to explain the observed phenomena. Based on the interview results, we assume that the level of experiment difficulty corresponds to the ability of students, who are able to work independently according to the prepared procedure and within the set time limit.

Students trained their skills in the chemistry laboratory, acquired knowledge on new separation methods and, last but not least, gained insight into new trends in organic chemistry trying to minimise adverse impact of industrial production on the environment and hence on human health.

\section{Acknowledgements}

This work was supported by VEGA 1/0166/16.

\section{References}

[1] Anastas PT, Warner JC. Green Chemistry: Theory and Practice. New York: Oxford University Press; 1998.

[2] Taylor DA. Principles into practice: setting the bar for green chemistry. Environ Health Perspect. 2010;118:254-257. DOI: 10.1289/ehp.118-a254.

[3] Sheldon RA. The E Factor: fifteen years on. Green Chem. 2007;9(12):1273-1283. DOI: 10.1039/B713736M.

[4] Liese A, Seelbach K, Wandrey Ch. Industrial Biotransformation. Weinheim: Wiley Verlag; 2006.

[5] Reetz MT. Biocatalysis in Organic Chemistry and Biotechnology: Past, Present, and Future. J Am Chem Soc. 2013;135(34):12480-12496. DOI: 10.1021/ja405051f.

[6] Bommarius AS., Riebelet BR. Biocatalysis: Introduction to Biocatalysis. Weinheim: Wiley-VCH; 2005.

[7] Buchholz K, Kasche V, Bornscheuer UT. Biocatalysts and Enzyme Technology. 2nd Edition. Weinheim: Wiley-VCH; 2012.

[8] Nakamura K, Yamanaka R, Matsudab T, Harada T. Recent developments in asymmetric reduction of ketones with biocatalysts. Tetrahedron Asymmetry. 2003;14(18):2659-2681. DOI: 10.1016/S0957-4166(03)00526-3.

[9] Müller M, Wolberg M, Schubert T, Hummel W. Enzyme-catalyzed regio- and enantioselective ketone reductions. Adv Biochem Engin/ Biotechnol. 2005;92:261-287. DOI: 10.1007/b98910.

[10] Wolberg M, Filho MV, Bode S, Müller M. Chemoenzymatic synthesis of the chiral sidechain of statins: Application of an alcohol dehydrogenase catalysed ketone reduction on a large scale. Bioprocess Biosyst Eng. 2008;31:183-191. DOI: 10.1007/s00449-008-0205-9.

[11] Weckbecker A, Gröger H, Hummel W. Regeneration of nicotinamide coenzymes: Principles and applications for the synthesis of chiral compounds. Adv Biochem Engin/ Biotechnol. 2010;120:195-242. DOI: 10.1007/10_2009_55.

[12] Goldberg K, Schroer K, Lütz S, Liese A. Biocatalytic ketone reduction - a powerful tool fot the production of chiral alcohols - part I: processes with isolated enzymes. Appl Microbiol Biotechnol. 2007;76:237-248. DOI: $10.1007 / \mathrm{s} 00253-007-1002-0$.

[13] Kumaraswamy G, Ramesh S. Soaked Phaseolus aureus: an efficient biocatalyst for asymmetric reduction of prochiral aromatic ketones. Green Chem. 2003;5:306-308. DOI: 10.1039/B300746D.

[14] Comasseto JV, Omori AT, Porto ALM, Andrade LH. Preparation of chiral organochalcogeno- $\alpha-$ methylbenzyl alcohols via biocatalysis: The role of Daucus carota root. Tetrahedron Lett. 2004;45:473-476. DOI: 10.1016/j.tetlet.2003.11.011.

[15] Wei Y, Xue D, Lei Q, Wanga Ch, Xiao J. Cyclometalated iridium complexes for transfer hydrogenation of carbonyl groups in water. Green Chem. 2013;15:629-634. DOI: 10.1039/C2GC36619C. 


\title{
BIOKATALITYCZNA REDUKCJA KETONÓW W LABORATORIUM SZKOLY ŚREDNIEJ
}

\begin{abstract}
Abstrakt: Biokataliza jest jedną z najważniejszych metod przemysłowych, która w coraz większym stopniu przyciąga uwagę naukowców jako metoda nowa i akceptowalna dla środowiska. Stosuje się ją do wytwarzania chiralnych alkoholi - ważnych cegiełek do syntezy wysokowartościowych chemikaliów, farmaceutyków, agrochemikaliów i analogów substancji naturalnych. W biokatalizie stosowanie tradycyjnych związków chiralnych na bazie metali ciężkich zostało zastąpione przez wykorzystanie enzymów. W wielu przypadkach liczba etapów reakcji została ograniczona, selektywność pożądanych produktów została zwiększona, a negatywny wpływ na środowisko został zmniejszony. Zasady biokatalizy zostały przez nas zastosowane w celu zaprojektowania prostego eksperymentu chemicznego dla uczniów szkół średnich II stopnia. Zmodyfikowane ćwiczenie laboratoryjne polegało na bioredukcji 4-nitroacetofenonu za pomocą enzymów obecnych w tkankach roślinnych marchwi, pietruszki i białej rzodkwi. W ramach naszych badań pedagogicznych przeanalizowano adekwatność eksperymentu chemicznego dla uczniów szkół średnich, a zrozumienie doświadczenia z zakresu zielonej chemii zostało zbadane za pomocą wywiadu półustrukturyzowanego.
\end{abstract}

Słowa kluczowe: biokataliza, zielona chemia, enzymy, eksperyment szkolny, wywiad półustrukturyzowany 